\title{
Strategi Pengembangan
} Perusahaan Agroindustri (Studi Kasus PT Citra Rahardja Utama di Kecamatan Gamping Kabupaten Sleman)

\author{
D 0 I:10.18196/ agr.1219
}

\begin{abstract}
This study aimed to analyze the appropriate strategy for PT Citra Utama Rahardja in maintaining business continuity. The case study method was used in this research, as PT Rahardja Citra Utama was a company that processes albasia wood (sengon) into barecore in Yogyakarta. The sources of data was taken from primary and secondary data. The results showed from SWOT analysis diagram was that layout of the company was in quadrant I, that was supported an aggressive strategy which included the integration of backward, forward, horizontal; market penetration; market development; product development; diversification (related or unrelated). Based on the calculation of SPACE matrix (Matrix of Strategic Position and Action Evaluation)
\end{abstract}

the coordinate of SPACE matrix diagram on the X-axis was 1,785 and Y-axis was 0,16 that was in quadrant I. The competition ability of PT Citra Utama Rahardja was considered as high and able to respond the variable of external factors.

Keywords: enterprise development strategy, barecore industry, SWOT Analysis, SPACE Analysis.

\section{INTISARI}

Penelitian ini bertujuan untuk menganalisis strategi prioritas untuk PT Citra Rahardja Utama dalam menjaga keberlanjutan bisnisnya. Metode penelitian yang digunakan adalah studi kasus, dimana PT Citra Rahardja Utama adalah sebuah perusahaan yang mengolah kayu sengon menjadi barecore di Yogyakarta. Sumber data yang digunakan terdiri atas data primer dan data sekunder. Hasil diagram analisis SWOT menunjukkan bahwa perusahaan berada di kuadran I, yang didukung strategi agresif yang meliputi integrasi ke belakang, integrasi ke depan, integrasi horizontal; penetrasi pasar;

pengembangan pasar; pengembangan produk; diversifikasi (terkait atau tidak terkait). Berdasarkan perhitungan matriks SPACE (Matrix of Strategic Position and Action Evaluation), koordinat pada diagram matriks SPACE yaitu sumbu $X$ 1,785 dan sumbu Y 0,16 kuadran I. Kemampuan bersaing PT Citra Utama Rahardja diianggap tinggi dan mampu tanggap terhadap perubah faktor eksternal.

Kata kunci: strategi pengembangan bisnis, industri barecore, analisis SWOT, analisis

\section{PENDAHULUAN}

Sengon (Albizia chinensis) adalah sejenis pohon anggota Sulen Fabaceae yang berpungsi sebagai pohon peneduh dan penghasil kayu. Pohon tersebut tersebar secara alami di India, Asia Tenggara, Cina Selatan, dan Indonesia sengon menyebar di Jawa, Bali dan Nusa Tenggara. Pengelolaan budidaya 
sengon mudah, kesesuaian tumbuh tidak sulit, kayunya serba guna dan memperbaiki kualitas serta kesuburan tanah. Sengon merupakan kayu multiguna, bisa digunakan sebagai bahan bangunan, lantai, pintu, dan ranting kayunya dapat dijual sebagai bahan baku pembuatan kertas ( $p$ ulp).

Perseroan Terbatas (PT) Citra Rahardja Utama merupakan perusahaan pengolahan kayu (wood working factory) yang secara resmi beroperasi pada tahun 2007. Lokasi perusahaan di Jl. Wates KM 9,5 Parangdewe, Desa Balecatur, Kecamatan Gamping, Kabupaten Sleman Yogyakarta. Ketinggian lokasi 112 meter di atas permukaan laut Bidang usaha PT Citra Rahardja Utama bergerak dalam bidang pengolahan kayu sengon termasuk dalam jenis industri kayu lapis laminasi termasuk Decorative Plywood, mengolah bahan baku berupa kayu balken menjadi barecore. Kayu balken adalah kayu sengon yang berbentuk balok (log kotak) yang digunakan untuk membuat barecore. Barecore merupakan produk olahan kayu berupa lembaran yang terdiri dari susunan kayu kecil-kecil. Bercore dapat digunakan sebagai bahan baku block board, hiasan pada dinding, sebagai alas lantai rumah sebelum diberi keramik atau diolah kembali menjadi produk kayu lainnya seperti meja, kursi, tempat tidur, dan lain-lain. Bahan baku albasia diperoleh dari daerah Klaten, Wonogiri, Kediri, dan Purwokerto. Maksud dan tujuan didirikan perusahaan PT Citra Rahardja Utama adalah untuk menjalankan usaha dalam bidang industri dan melakukan usaha perdagangan lokal maupun luar negri. Permintaan pasar internasional terhadap sengon dan olahannya terus meningkat, sebagai apresiasi terhadap kayu budidaya, harganya diperkirakan akan terus meningkat.

Perkembanagan dan eksistensi suatu perusahaan dipengaruhi oleh faktor internal dan eksternal, sehingga suatu perusahaan harus mengetahui keadaan perusahaan sendiri dan keadaan perusahaan lain baik mengenai kekuatan maupun kelemahannya. Dengan diketahui kekuatan dan kelemahan perusahaan dan perusahaan lain, diharapkan perusahaan mampu mengantisipasi setiap ancaman yang ada.Selain itu perusahaan harus mampu mengamati setiap peluang untuk memperluas pangsa pasar perusahaan.

Faktor internal dari PTCitra Rahardja Utama seperti kualitas produk, kontinuitas produksi, kemampuan dan pengalaman manajerial, profesionalisme tenaga kerja, pengembangan tenaga kerja, kemampuan untuk meraih penjualan. Kelemahan perusahaan seperti investasi perusahaan untuk pengembangan produk kemampuan meraih penjualan, pemasaran ke pasar luar negri, pemeliharaan dan penggantian alat produksi, lokasi perusahaan dekat dengan rumah penduduk, luas pabrik tidak bisa ditambah, gudang yang terlalu kecil. Sedangkan faktor eksternalnya untuk peluang yang dimiliki perusahaan adalah pertumbuhan pasar barecore yang besar, adanya pembeli tetap, semakin banyak areal tanaman sengon, dukungan masyarakat dan pemerintah.. Ancaman perusahaan yang dihadapi persaingan dengan perusahaan barecore lain, bahan baku sengon yang harus bersertifikat, kenaikan tarif listrik, kelangkaan bahan baku, upah tenaga kerja yang selalu meningkat.

Strategi perusahaan merupakan garis besar haluan perusahaan, kebijaksanaan dan taktik perusahaan yang merupakan penerjemahan lebih lanjut strategi yang telah ditetapkan (Sukanto dan Siswanto, 1990). Dalam upaya meningkatkan eksistensi perusahaan, strategi perusahaan memegang peranan penting, banyak perusahaan yang tidak mampu mencapai pasar penjualan yang mengakibatkan tidak tercapainya tujuan perusahaan, hal ini disebabkan tidak tepatnya strategi perusahaan yang diterapkan. Oleh karena itu perlu dilakukan penelitian untuk menganalisis pilihan strategi pada perusahaan dan untuk mengetahui keputusan strategi pengembangan yang tepat.

\section{METODE PENELITIAN}

Metode penelitian yang digunakan adalah metode studi kasus (case study), yakni penelitian tentang status obyek penelitian yang berkenaan dengan suatu fase spesifik atau khas dari seluruh personalitas (Maxfield dalam Nazir), yang bertujuan untuk memberikan gambaran secara mendetail tentang latar belakang, sifatsifat serta karakter-karakter yang khas dari kasus, sifatsifat yang khas yang kemudian akan dijadikan suatu hal yang bersifat umum. (Nazir, 1983). Penelitian ini merupakan studi kasus di PT Citra Rahardja Utama, perusahaan yang mengolah kayu albasia, hasil produksi barecore yang ada di Daerah Istimewa Yogyakarta. Luas lahan kegiatan perusahaan sebesar $3.721 \mathrm{~m} 2$ dengan kapasitas produksi $580.476 \mathrm{~m} 3 /$ bulan. Jumlah tenaga kerja sebanyak 117 orang. PT Citra Rahardja Utama menghasilkan produk yang memiliki prospek yang baik dan sebagian besar hasil produksinya diekspor. Data yang digunakan dalam penelitian ini adalah data primer dan sekunder. Data primer merupakan data yang didapat dari 
sumber pertama baik dari individu atau perseorangan (Umar, 2014). Data sekunder adalah pengambilan data yang dihimpun melalui tangan kedua (Riduwan, 2013).

Proses manajemen strategis dapat diaplikasikan dengan menggunakan model manajemen strategis komprehensif, sebuah pendekatan yang jelas dan praktis untuk merumuskan, menerapkan dan menilai strategi (David, 2012). Penerapan strategi perusahaan PT Citra Rahardja Utama didasarkan perhitungan matrik faktor strategi internal (IFAS) dan matrik faktor strategi eksternal (EFAS). Metode analisis yang digunakan dengan analisis SWOT yang dilanjutkan dengan matriks Posisi Strategis dan Evaluasi Tindakan (SPACE).StrengthsWeaknesses-Opportunities-Threats (SWOT) adalah sebuah alat pencocokan yang penting yang membantu para manajer mengembangkan empat jenis strategi yaitu strategi SO (kekuatan-peluang), strategi WO, strategi WT, dan strategi ST.Tujuan digunakan analisis ini untuk mengidentifikasi kekuatan dan kelemahan yang diperoleh dari analisis lingkungan internal perusahaan dan mengidentifikasi peluang dan ancaman yang diperoleh dari analiisis lingkungan eksternal perusaahan. Langkah dalam analisis SWOT adalah menentukan faktor-faktor strategis yang menjadi kekuatan dan kelemahan perusahaan, masing-masing faktor diberi bobot dari sangat penting sampai tidak penting terhadap posisi strategis perusahaan. Untuk faktor kekuatan perusahaan dimulai dari 1 sampai 4 (sangat baik), sebaliknya untuk faktor kelemahan dimulai dari 4 sampai 1. Mengalikan bobot dengan rating untuk memperoleh skor pembobotan perusahaan. Menentukan faktor-faktor strategis yang menjadi peluang dan ancaman, memberi bobot dan rating masing-masing faktor dan mengalikan bobot dan rating untuk memperoleh skor pembobotan perusahaan.

Matriks Strategic, Position, and Action Evaluation (SPACE), matriks ini merupakan empat-kuadran yang menunjukkan apakah agresif, konservatif, defensif atau kompetitif yang paling sesuai untuk suatu organisasi. Sumbu-sumbu matriks SPACE menunjukkan dua dimensi internal dan keunggulan kompetitif, dan dua dimensi eksternal stabilitas lingkungan dan kekuatan industri. Keempat faktor ini merupakan penentu terpenting dari posisi strategis keseluruhan suatu organisasi (David, 2012).

\section{HASIL DAN PEMBAHASAN MATRIKS SWOT}

Matriks Kekuatan - Kelemahan - Peluang-Ancaman (Strengths - Weaknesses - Opportunities-Threats/SWOT) adalah suatu alat pencocokan yang penting yang membantu para manajer mengembangkan empat jenis strategis.Digunakan untuk menganalisis lingkungan internal meliputi kekuatan dan kelemahan dan analisis lingkungan eksternal yang meliputi peluang dan ancaman, untuk merumuskan strategi perusahaan yang tepat diterapkan pada perusahaan PT Citra Rahardja Utama.

\section{ANALISIS LINGKUNGAN INTERNAL KEKUATAN}

a. Kontinuitas produksi

Keberlangsungan industri pengolahan kayu PT Citra Rahardja Utama ini tidak terlepas dari kontinuitas produksi yang dilakukan secara terus menerus sesuai dengan standar operasional kualitas produk.

b. Kualitas produk

Kualitas produk PT Citra Rahardja Utama termasuk bagus dilihat dari hasil produk yang rata, produknya tidak berlubang, dan kuat tidak mudah ambrol.

c. Letak fasilitas fisik pabrik

Sebuah perusahaan penataan fasilitas produksi merupakan salah satu faktor pendukung dalam efektivitas perusahaan. Perencanaan tata letak produksi (tata letak mesin pemotong, oven) harus dipikirkan juga mengenai sistem pemindahan bahan. Proses pemindahan bahan akan menentukan keterkaitan antara satu fasilitas dengan fasilitas produksi yang lain.

d. Pengalaman manajerial

Pengalaman, kemampuan manajer dalam menjalankam perusahaan sudah baik, berdasarkan keberadaan pabrik yang sampai sekarang masih beroperasi.

e. Profesionalisme tenaga kerja

Profesionalisme operasi tenaga kerja sudah cukup baik , semua tenaga kerja bekerja harus memenuhi standar mutu operasional. Tenaga kerja yang diangkat adalah tenaga kerja yang memenuhi kualifikasi pekerjaan dan sesuai keahlian untuk pekerjaan 
operasional industri pengolahan kayu.

f. Letak perusahaan tidak jauh dari bahan baku Letak PT Citra Rahardja Utama di jalan Jogja-Wates Km 9,5 Perenggawe Balecatur Gamping Sleman. Letak pabrik sangat strategis, sehingga memudahkan dalam pemenuhan bahan baku yang diperlukan untuk proses produksi dan pengangkutan hasil produksi untuk dipasarkan.

g. Pengembangan tenaga kerja Untuk meningkatkan kinerja, tenaga kerja diikutkan dalam kursus/pelatihan yang bisa mendukung dalam bekerja.

h. Memasang alat pengendalian pencemaran udara pada boiler

Pengoperasian boiler sesuai Standar Operation Procedur (SOP) sehingga tidak terjadi kerusakan dan pencemaran emisi, menghubungkan mesin produksi ke alat pengendalian pencemaran udara (dust cbolector)menyalurkan/menghubungkan boiler dan genset ke alat pengendali pencemaran emisi udara (cyclon).

i. Pengelolaan lingkungan hidup Sudah dilakukannya analisis laboratorium terhadap pengukuran kualitas lingkungan di sekitar lokasi PT Citra Rahardja Utama meliputi: kualitas udara dan kebisingan yaitu dengan membuat pagar pembatas permanen setinggi 3 meter mengelilingi seluruh areal kegiatan, melakukan bongkar muat hanya pada jam kerja dan menghentikan kegiatan pada malam hari saat jam istirahat penduduk, pembuatan buffer zone dengan menanam pohon perindang;saluran drainase dibuat dengan desain saluran terbuka yang terhubung ke saluran drainase di pinggir jalan raya Jogja-Wates dan saluran drainase sisi selatan; memasang rambu peringatan bahaya kebakaran pada lokasi rawan kebakaran dan jalur evakuasi pada setiap ruangan.

j. Memberikan jaminan asuransi kesehatan kepada seluruh karyawan

Melakukan pengecekan kesehatan karyawan secara berkala; karyawan mengenakan alat pelindung diri saat melakukan pekerjaan yang berpotensi kecelakaan kerja; semua karyawan diikutkan asuransi Jamsostek.

\section{KELEMAHAN}

a. Investasi perusahaan untuk pengembangan produk Investasi pengembangan masih kurang dan perlu mendapatkan perhatian. Untuk investasi pengembangan dibutuhkan dana yang besar sehingga perlu waktu untuk menyiapkan. Karena PT Citra Rahardja Utama termasuk skala usaha yang kecil, sehingga kesulitan di dalam pengembangan produk yang sangat membutuhkan investasi banyak. Inovasi pengembangan produknya dengan membuat produk lanjutan yaitu blockboard, ini perlu investasi pengembangan yang lebih besar.

b. Kemampuan meraih penjualan

Karena perusahaan termasuk dalam skala usaha kecil, maka produksinya per bulan juga kecil, sehingga tidak bisa menjual ke berbagai pembeli. Jika PT Citra Rahardja Utama mampu meraih penjualan ke berbagai pembeli bisa mendatangkan keuntungan yang besar, namun masih tergantung kinerja perusahaan dalam mengatasi kendala-kendala internal dan eksternal.

c. Pemasaran ke pasar luar negri

Penjualan produk ke pasar luar negri masih tergantung dengan pihak ketiga (broker). Perusahaan sebenarnya bisa menjual secara langsung ke pembeli di negara lain, tetapi hal ini memerlukan proses/prosedur yang cukup panjang. Proses tersebut hanya bisa dilakukan oleh perusahaan yang cukup besar, dan proses tersebut memerlukan kemampuan manajemen yang lebih tinggi.

d. Pemeliharaan dan penggantian alat produksi Pemeliharaan dan penggantian alat produksi membutuhkan biaya yang besar, sehingga perlu mendapat perhatian dari perusahaan. Alat-alat produksi yang ada sekarang ini sebagian besar sudah lama dan termasuk sudah ketinggalan jaman, sehingga mengakibatkan proses produksinya kurang efisien. Dengan kondisi seperti itu, maka perlu penggantian alat-alat mesin produksi yang lebih modern dan canggih.

e. Lokasi dekat dengan rumah penduduk Lokasi PT Citra Rahardja Utama di tengah-tengah pemukiman penduduk, sehingga perusahaan kesulitan 
jika akan memperluas areal. Karena lokasi perusahaan di dekat rumah penduduk, maka perusahaan tidak bisa berproduksi pada malam hari, proses produksinya terbatas hanya bisa dilakukan pada siang hari.

f. Luas pabrik tidak bisa ditambah

Untuk bisa menambah produksi atau memperbesar skala usaha perusahaan, maka areal luas pabrik perlu diperbesar. Tetapi dengan melihat lokasi pabrik sekarang ini, di dekat pabrik sudah penuh dengan bangunan-bangunan rumah,maka pabrik mengalami kesulitan untuk bisa menambah luas arealnya.

g. Gudang yang terlalu kecil

Untuk menyimpan hasil produksi perlu adanya gudang yang mencukupi. Produksi yang dihasilkan PT Citra Rahardja sebesar 600 m3/bulan, kapasitas gudang hanya $300 \mathrm{~m} 3$, sehingga produksi harus bisa dijual dengan cepat dan tidak boleh melebihi waktu 2 minggu.

\section{ANALISIS LINGKUNGAN EKSTERNAL PELUANG}

a. Pertumbuhan pasar barecore

Produk barecore bisa dimanfaatkan untuk berbagai macam keperluan rumahtangga dan perusahaan. Kebutuhanbarecore untuk negara Cina sekitar 40005000 kontainer/bulan, 1 kontainer berisi 58 m3barecore. Sementara kemampuan produsen barecore sebesar99 \% untuk pasar Cina didominasi oleh negara Indonesia. Pabrik barecoreyang ada di Indonesia sebanyak 150 pabrik. Produktivitas pabrik sebesar2500 kontainer/bulan. Walaupun peluangnya masih besar tetapi harga barecore berfluktuatif. Harga berfluktuatif karena dipermainkan oleh 4 trader besar Cina. Trader tersebut kemudian menjual ke perusahaan-perusahaan Cina. Dengan berfluktuatifnya harga barecore, maka perlu adanyausaha untuk normalisasi harga. Normalisasi harga bisa dilakukan dengan cara membuat buffer stock (harga penyangga). Untuk bisa melakukan buffer stock dibutuhkan dana yang cukup banyak yaitu sebesar Rp 3 Trilyun.Hal tersebut tidak mungkin dilakukan oleh pengusaha barecore Indonesia, sehingga diperlukan adanya turun tangan dari pemerintah. Hal ini penting karena penjualan daribarecore mampu menyumbang devisa negara sebesar US \$ 500/tahun.

b. Adanya pembeli tetap

Dengan adanya pembeli tetap menunjukkan pasar dari PT Citra Rahardja Utama sudah jelas dan besar. Kebutuhan barecore selalu ada. Sebenarnya tujuan ekspor selain negara Cina, masih ada beberapa negara yang menjadi pasar barecore yaitu negara Timur Tengah, negara Eropa Pasar - pasar tersebut masih terbuka luas untuk tujuan ekspor.

c. Pemasok kayu sengon

PT Citra Rahardja Utama bekerja sama dengan petani sengon untuk persediaan bahan baku. Dengan tersedianya bahan baku secara kontinyu maka produksi akan berjalan dengan lancar. Kayu sengon banyak tumbuh subur di negara Indonesia. Bahan baku kayu sengon (albasia) yang dihasilkan negara Indonesia kualitasnya lebih baik daripada kualitas sengon dari negara lain/kompetitor yaitu negara Pilipina, New Zealand maupun dari Kanada.

d. Semakin banyak areal tanaman sengon Tanaman sengon termasuk umurnya pendek dan harga jualnya tinggi, sehingga memberikan prospek yang bagus.Hal ini dapat dilihat dari semakin banyaknya areal tanaman sengon yang diusahakan oleh petani.

e. Dukungan masyarakat

Masyarakat sekarang banyak yang menanam sengon (albasia), karena harga sengon yang menarik, tanaman sengon mudah tumbuh dan mudah cara budidayanya.

\section{ANCAMAN}

a. Persaingan dengan pabrik barecore lain

Di Indonesia sekarang banyak pemain-pemain besar perusahaan barecore. Sekarang banyak perusahaan besar menanamkan investasi di bidang barecore, seperti pabrik-pabrik rokok banyak yang beralih ke barecore, seperti pabrik rokok Djarum, pabrik rokok Gudang Garam, dan lain-lain.

b. Adanya penerapan SVLK (Sertifikasi Verifikasi Legalitas Kayu)

SVLK yang diterapkan kepada para petani (usaha penggergajian kayu/sawmill), membebani para petani 
TABEL I. PENILAIAN FAKTOR INTERNAL

\begin{tabular}{cccc}
\hline Fakkor-faktor Strategis Internal & Bobot & Rating & Bobot x Rating \\
\hline Kekuatan: & & & \\
1. Kontinuitas produksi stabil & 0,10 & 5,0 & 0,50 \\
2. Kualitas produk tinggi & 0,10 & 5,0 & 0,50 \\
3. Letak fasilitas fisik (layoù pabrik & 0,05 & 4,0 & 0,20 \\
4. Pengalaman manajerial & 0,07 & 3,5 & 0,245 \\
5. Profesionalisme tenaga kerja & 0,05 & 5,0 & 0,25 \\
6. Letak perusahaan tidak jauh dari bahan baku & 0,05 & 3,5 & 0,175 \\
7. Pengembangan tenaga kerja & & & \\
8. Memasang alat pengendalian pencemaran udara pada boiler & 0,05 & 4,5 & 0,225 \\
9. Pengelolaan lingkungan hidup & 0,05 & 3,0 & 0,15 \\
10. Memberikan jaminan asuransi kesehatan kepada seluruh karyawan & 0,06 & 3,0 & 0,18 \\
& 0,05 & 3,5 & 0,175 \\
& & & 2,6 \\
Kelemahan: & & & \\
1. Investasi perusahaan untuk pengembangan produk & 0,05 & 2,0 & 0,1 \\
2. Kemampuan meraih penjualan & & & \\
3. Pemasaran ke pasar luar negri & 0,05 & 2,0 & 0,1 \\
4. Pemeliharaan dan penggantian alat produksi & 0,05 & 1,5 & 0,075 \\
5. Lokasi dekat dengan rumah penduduk & 0,05 & 3,0 & 0,15 \\
6. Luas pabrik tidak bisa ditambah & 0,05 & 3,0 & 0,15 \\
7. Gudang yang terlalu kecil & 0,06 & 2,0 & 0,12 \\
& 0,06 & 2,0 & 0,12 \\
& 1,00 & & 0,815 \\
& & & 3,415 \\
\hline
\end{tabular}

TABEL 2. PENILAIAN FAKTOR EKSTERNAL

\begin{tabular}{cccc}
\hline Faktor-faktor Strategi Eksternal & Bobot & Rating & Bobot x Rating \\
\hline Peluang : & & & \\
1. Pertumbuhan pasar barecore yang besar & 0,07 & 3 & 0,21 \\
2. Adanya pembeli tetap & 0,06 & 4 & 0,24 \\
3. Bahan baku tersedia & 0,15 & 5 & 0,75 \\
4. Semakin banyak areal tanaman sengon & 0,11 & 5 & 0,55 \\
5. Dukungan masyarakat & 0,07 & 5 & 0,35 \\
& & & 2,10 \\
Ancaman : & & & \\
1. Persaingan dengan pabrik barecore lain & 0,07 & 3 & 0,21 \\
2. Penerapan SVLK & 0,06 & 2 & 0,12 \\
3. Bahan baku sengon yang harus bersertifikat & 0,12 & 5 & 0,60 \\
4. Kelangkaan bahan baku & 0,11 & 1 & 0,11 \\
5. Kenaikan tarif listrik & 0,11 & 5 & 0,55 \\
6. Upah tenaga kerja yang selalu meningkat & 0,07 & 5 & 0,35 \\
& 1,00 & & 1,94 \\
\end{tabular}


kayu sengon atau penggergaji kayu. Petani sengonkalau akan menjual ke pabrik harus mempunyai sertifikat. Biaya sertifikasi sebesar Rp010.000.000/tahun, untuk ijin Usaha Dagangnya sekitar Rp 5.000.000, pembuatan ijin lainnya sekitar $\mathrm{Rp} 5.000 .000$. Selain itu harus mengikuti kursus sebagai tenaga teknis untuk sertifikasi (GANIS)sebesarRp 9.000.000. Di samping itu Tenaga teknis harus berpendidikan minimal SMA.

c. Bahan baku sengon yang harus bersertifikat Adanya kayu sengon harus bersertifikat menyulitkan penggergajian kayu karena dibutuhkan biaya yang besar, skill yang tinggi, pendidikan minimal SMA. Lokasi penggergajian harus di daerah industri dan di tanah pekarangan. Lokasi penggergajian kayu yang selalu berpindah-pindah, menyebabkan pabrik kesulitan untuk mendapatkan bahan baku. Bahan baku yang diperoleh pabrik jika tidak bersertifikat, perusahaan akan memproleh sangsi.

d. Kenaikan tarif listrik

Biaya listrik semakin naik. Lima (5) tahun yang lalu biaya listrik sebesar Rp16.000.000/bulan, sekarang meningkat menjadi Rp 60.000.000/bulan. Dengan kenaikan biaya listrik yang terus menerus maka perusahaan akan bisa terancam.

e. Kelangkaan bahan baku

Petani tidak bisa menjual, maka pengadaan bahan baku tersendat, tidak lancar.

f. Upah tenaga kerja yang selalu meningkat Karena gerakan serikat buruh pabrik yang selalu menuntut kenaikan upah, menyebabkan biaya tenaga kerja produksi pabrik akan meningkat.

Untuk menentukan strategi perusahaan yang tepat diterapkan pada perusahaan PT Citra Rahardja Utama, dapat dilakukan dengan diagram analisis SWOT. Dari perhitungan dapat diketahui pada faktor internal total bobot $\mathrm{x}$ rating yaitu sebesar 0,815 dan pada faktor eksternal sebesar 1,94. Sehingga pada diagram analisis SWOT, letak perusahaan PT Citra Rahardja Utama berada pada kuadran I, yaitu mendukung strategi agresif. Perusahaan PT Citra Rahardja Utama dapat menggunakan seluruh kekuatan yang dimiliki untuk memanfaatkan peluang yang ada, dapat dilihat pada gambar.

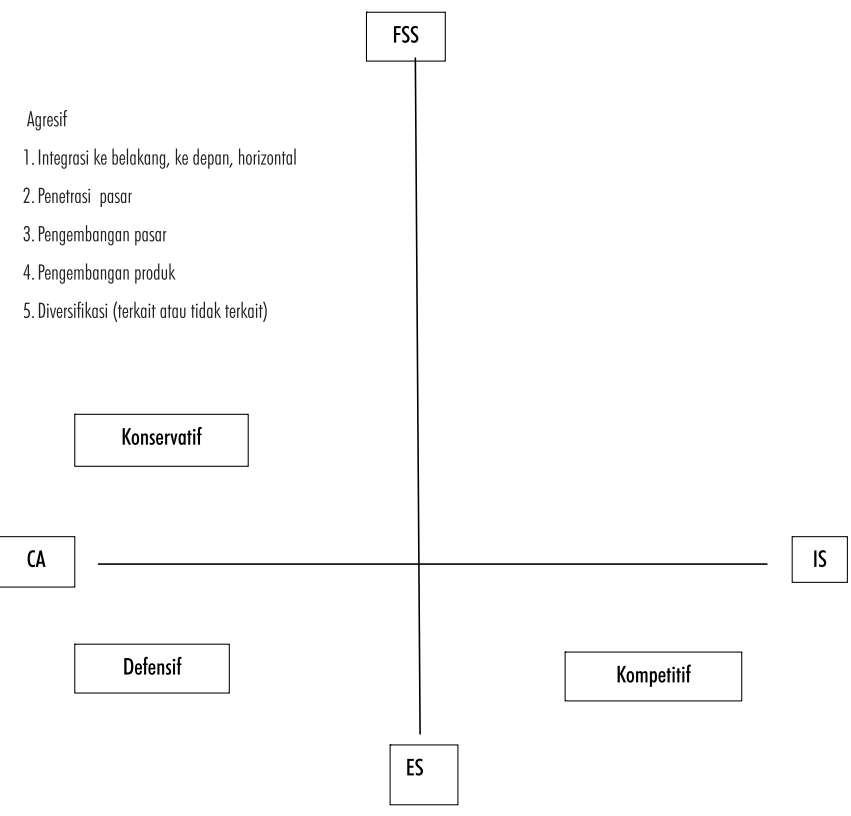

Keterangan :

FS : Financial Strength

CA: Competitive Advantage

ES : Environmental Stability

IS : IndustrySrength

Matriks Posisi Strategis dan Evaluasi Tindakan (SPACE). Berdasarkan perhitungan matriks SPACE, dapat diperoleh koordinat diagram matriks SPACE yaitu pada sumbu X sebesar 2,6 - 0,815 =1,785 dan pada sumbu Y sebesar 2,10 - 1,94 $=0,16$ yaitu pada kuadran I. Dari hasil perhitungan memperlihatkan bahwa kemampuan bersaing PT Citra Rahardja Utama diianggap tinggi dan mampu tanggap terhadap perubah faktor eksternal. Dapat disimpulkan bahwa PT Citra Rahardja Utama merupakan perusahaan yang memiliki daya saing yang tinggi. Hal ini dapat terilihat dari pabrik-pabrik yang lain sudah tutup, mengurangi produksinya, PT Citra Rahardja Utama tetap berproduksi dalam kapasitas penuh. Hasil pemetaan antara tingginya pertumbuhan pasar dan daya saing perusahaan menunjukkan bahwa PT Citra Rahardja Utama terletak pada kuadran I, strategi yang cocok:

1. Integrasi ke belakang: untuk mengatasi kelangkaan bahan baku dengan cara memperpendek saluran suplier bahan baku, langsung ke penggergajian atau membuat bahan baku sendiri;

Integrasi ke depan: merangkul buyer dengan 
menjual langsung ke konsumen atau pengguna, tidak melalui trader (pedagang perantara);

Integrasi horizontal: kerjasama antar sesama produsen barecore untuk membuat asosiasi untuk meningkatkan bargaining power sehingga bisa menjual dengan harga tinggi.

2. Penetrasi pasar: menurut Umar (1999), berdasarkan pada kondisi perusahaan, petunjuk mengenai strategi bisnis yang paling efektif untuk mengimplementasikan strategi tersebut adalah kebutuhan konsumen yang ada akan produk dapat ditingkatkan.

3. Pengembangan pasar: tidak hanya eksport ke Cina saja tetapi juga ke Timur Tengah, Jepang, dan Eropa

4. Pengembangan produk: selain memproduksi barecore, juga memproduksi blok board ( yaitu barecore dilapisi lembaran kayu tipis/veneel)

5. Diversifikasi yang terkait: limbah dibuat briket arang.

\section{KESIMPULAN}

1. Dari perhitungan dengan analisis SWOT dapat diketahui PT Citra Rahardja Utama faktor internal sebesar 0,815 dan pada faktor eksternal sebesar 1,94. Sehingga pada diagram analisis SWOT, letak perusahaan berada pada kuadran I, yaitu mendukung strategi agresif, meliputi (a) integrasi ke belakang, ke depan, horizontal; (b) penetrasi pasar; (c) pengembangan pasar; (d) pengembangan produk; dan (e) diversifikasi (terkait atau tidak terkait).

2. Berdasarkan perhitungan matriks SPACE, dapat diperoleh koordinat diagram matriks SPACE yaitu pada sumbu $X$ sebesar 2,6 - 0,815 = 1,785 dan pada sumbu Y sebesar 2,10 $-1,94=0,16$ yaitu pada kuadran I. Dari hasil perhitungan memperlihatkan bahwa kemampuan bersaing PT Citra Rahardja Utama diianggap tinggi dan mampu tanggap terhadap perubah faktor eksternal.

\section{DAFTAR PUSTAKA}

Anonim. 2014. Laporan Pelaksanaan Upaya Pengelolaan Lingkungan Hidup dan Upaya Pemantauan Lingkungan Hidup

Daviid. R. Fred. 2012. Manajemen Strategis Konsep. Buku 1
Edisi 12. Salemba Empat, Jakarta

Hunger. JD \& Wheelen. TL. 2001. Manajemen Strategis. Andi Offset, Yogyakarta

Kotler, Philip. 2002. Manajemen Pemasaran Edisi Milenium Jilid 1. Prenhallindo, Jakarta

Kuncoro, Mudrajad. 2005. Strategi Bagaimana Meraih Keunggulan Kompetitif. Erlangga, Jakarta

Nazir, M. 1988. Metode Penelitian. Ghalia Indonesia, Jakarta

Riduwan, 2013. Belajar Mudah Penelitian untuk GuruKaryawan dan Peneliti Pemula. CV. Alfabeta. Bandung Umar, Husein. 2000. Riset Pemasaran dan Perilaku

Konsumen. Gramedia Pustaka Utama, Jakarta 2014. Metode Penelitian Untuk Skripsi dan Tesis

Bisnis, Edisi Kedua, Cetakan Ketigabelas. PT Raja

Grafindo. Jakarta 